\title{
Characteristics of Bituminous Concrete Mixtures Utilizing Copper Slag.
}

\section{Características de las mezclas de hormigón bituminoso que utilizan escoria de cobre}

Chavan Ravishankar*, M.S.Nagakumar, Krishnegowda H K, Abhilash R Prasad

\section{Civil Engineering Department}

R V College of Engineering (Visvesvaraya Technological University, Belgaum)

Bengaluru, India

*Corresponding mail id: hobicons@gmail.com

\begin{abstract}
Study work on the effectiveness and use of Industrial by-products (IBP) in flexible pavements is restricted. Several factors however need to be analyzed specifically before a greater proportion of industrial by-products can be used in bituminous concrete mixtures with a high level of confidence. Effects of copper slag on volumetric and strength parameters such as Marshall Parameters, static tensile properties, and moisture resistivity of bituminous concrete mixtures using copper slag as mineral fillers need to be examined and thoroughly analyzed. Quantitative analyses of the elements and the morphology of the copper slag have been studied by Energy Dispersive X-ray Analyzer (EDX) and Scanning Electron Microscope (SEM). The use of copper slag as a mineral filler in bituminous concrete grade-2 mixtures showed an increase in stability, indirect tensile strength, and moisture resistance compared to traditional mixtures.
\end{abstract}

Keywords - Industrial by-products (IBP), Indirect Tensile Strength, Moisture resistivity, SEM, EDX

\section{RESUMEN}

Se restringe el trabajo de estudio sobre la efectividad y uso de Subproductos Industriales (IBP) en pavimentos flexibles. Sin embargo, varios factores deben analizarse específicamente antes de que se pueda utilizar una mayor proporción de subproductos industriales en mezclas de hormigón bituminoso con un alto nivel de confianza. Los efectos de la escoria de cobre sobre los parámetros volumétricos y de resistencia, como los 
Sustainability, Agri, Food and Environmental Research, (ISSN: 0719-3726), 10(X), 2022:

http://dx.doi.org/

parámetros Marshall, las propiedades de tracción estática y la resistividad a la humedad de las mezclas de hormigón bituminoso que utilizan escoria de cobre como cargas minerales, deben examinarse y analizarse a fondo. Los análisis cuantitativos de los elementos y la morfología de la escoria de cobre han sido estudiados por Energy Dispersive X-Ray Analyzer (EDX) y Scanning Electron Microscope (SEM). El uso de escoria de cobre como relleno mineral en mezclas de hormigón bituminoso de grado 2 mostró un aumento en la estabilidad, la resistencia a la tracción indirecta y la resistencia a la humedad en comparación con las mezclas tradicionales.

Palabras clave: subproductos industriales (IBP), resistencia a la tracción indirecta, resistividad a la humedad, SEM, EDX

\section{INTRODUCTION}

Environmental, economic and technological issues have led to greater attention being paid to the issue of marginal materials recycling in the development of road infrastructure [Huang et.al, 2007]. The performance of marginal materials as components of transport infrastructure has been studied for several years. In specific, their physical-mechanical characteristics have been determined in order to define the right ways and methods of using them on the highways. Pundhir N K and Nanda P K [Pundhir et.al, 2005] have analysed and concluded that the use of the copper industry by-product (CS) as fine aggregates in different bituminous mixtures not only provides strong interlocking, but also improves the volumetric parameters and the mechanical parameters of the mixtures. B. Jayashree et al have shown that the DBM grading -2 with CS-15\% enhanced the volumetric and indirect TSR parameters [Jayasree et. al, 2016]. It is observed that mixtures [Sankarlal,2017] with CSFA-20 percent had a high stability value relative to mixtures with CSFA-30\% and CSFA-40 percent. Havanagi [Havanagi, 2009] stated that the utilization of the copper slag (CS) as an FA content in bituminous concrete mixtures was found to be significantly higher. Hassan [Hassan and AlJabri, 2011] reported the effects of granulated copper slag (CSFA) on bituminous concrete mixtures and showed significantly higher potential for resistance to rutting for mixtures with increased slag content.

\section{Objectives}

This research paper investigates the effectiveness of copper industry by-products (CS) as mineral filler (MF) in bituminous concrete in mid-limit grade-2 mixtures (BC2) by 
Sustainability, Agri, Food and Environmental Research, (ISSN: 0719-3726), 10(X), 2022:

http://dx.doi.org/

experimental studies. Other tests related to performance parameters (Split tensile strength, and Split tensile strength ratio) have been measured through ITS.

\section{MATERIALS AND METHODS}

The Marshall mixture design method is used for the preparation of bituminous concrete based on IRC codes, mid-limit Grading-2 mixtures (BC2) of 25, 50, 75 and 100 CS-MF replacements percentage using VG-30 bitumen. Tests are carried out on aggregates and VG30 as per Indian Standard (IS) Test Procedure and Indian Road Congress Requirements and are tested for their suitability in bituminous grade- 2 concrete mixtures. Preliminary studies are performed to evaluate the OBC (optimal bitumen content) through Marshall Mixture design. Upon arrival at $\mathrm{OBC}$ for $0,25,50,75$ and 100 percent copper slag replacements in bituminous mixtures are considered preferential and laboratory performance tests are performed: Static Indirect Tensile Strength tests, and Moisture Resistance tests respectively.

In the present analysis, stone aggregates were obtained from Bidadi Granite quarry, Bidadi, Ramanagaram, Karnataka, India. Copper slag was collected from the Chitradurga Copper Mining Industry, Chitradurga District, Karnataka, India. Grain size distribution, morphological characteristics, physical and chemical properties have been analysed by SEM \& EDX technologies and the findings of GSA of industrial by-products (IBP) are shown in Fig.1. The aggregate gradation relative to the Bituminous Concrete Mix grading-2 mid-limit gradation was assigned in accordance with Section 500 of Table No.500-18 of MORT\&H (Ministry of Road Transport and Highways) of the Fourth Revision Specification and is summarised in Table 1.

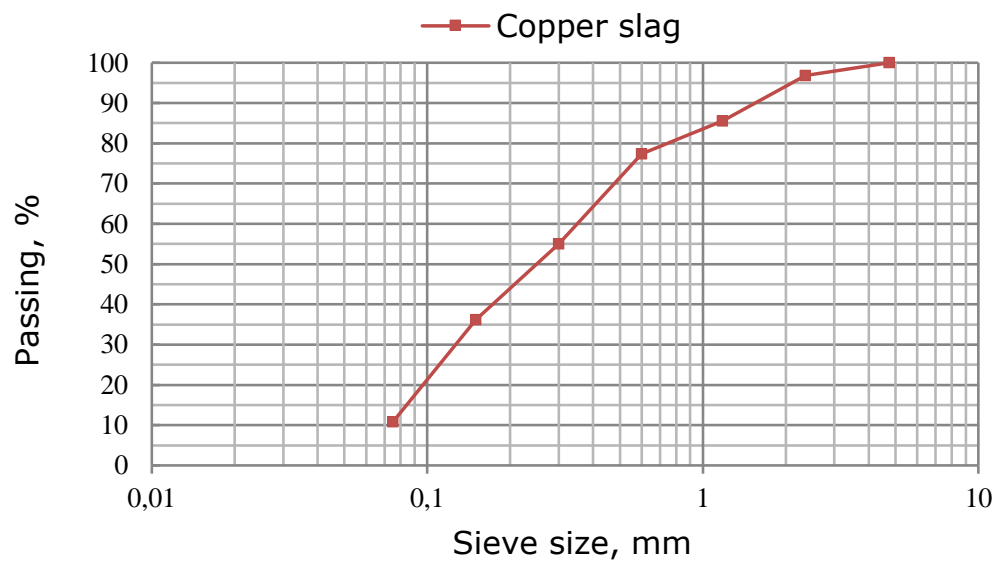

Fig. 1 Grain size distribution for Industrial by-products 
Sustainability, Agri, Food and Environmental Research, (ISSN: 0719-3726), 10(X), 2022:

http://dx.doi.org/

Table 1 Gradation table for BC2 mixtures

\begin{tabular}{|c|c|c|c|c|}
\hline $\begin{array}{l}\text { IS } \\
\text { Sieve } \\
\text { size } \\
(\mathrm{mm})\end{array}$ & $\begin{array}{l}\text { Range } \\
\text { of } \\
\text { gradati } \\
\text { on }\end{array}$ & $\begin{array}{c}\text { Adopted } \\
\text { gradation (Mid } \\
\text { limit percentage } \\
\text { passing) }\end{array}$ & $\begin{array}{l}\text { Percentage } \\
\text { Retained on } \\
\text { sieve sizes }\end{array}$ & $\begin{array}{l}\text { Percent of IBP- } \\
\text { FAMF content }\end{array}$ \\
\hline 19 & 100 & 100 & 10.5 & 0 \\
\hline 13.2 & $79-100$ & 89.5 & 10.5 & 0 \\
\hline 9.5 & $70-88$ & 79 & 17 & 0 \\
\hline 4.75 & $53-71$ & 62 & 12 & 0 \\
\hline 2.36 & $42-58$ & 50 & 9 & 0 \\
\hline 1.18 & $34-48$ & 41 & 9 & 0 \\
\hline 0.6 & $26-38$ & 32 & 9 & 0 \\
\hline 0.3 & $18-28$ & 23 & 7 & 0 \\
\hline 0.15 & $12-20$ & 16 & 9 & 0 \\
\hline 0.075 & $4-10$ & 7 & 7 & $\begin{array}{c}0,25,50,75 \& \\
100\end{array}$ \\
\hline
\end{tabular}

Copper slag (CSMF) Mineral filler contents of 0, 25, 50, 75 and 100 percentage were chosen for the preparation of BC-2. The conventional aggregates and the copper slag were tested experimentally in compliance with the stated test procedure for the evaluation of the basic properties. The quarry stone aggregate used for this analysis is found to satisfy the specification requirements as stated under section 500, Table No. 500-17 of IRC code and the findings are summarized in Table 2. 
Sustainability, Agri, Food and Environmental Research, (ISSN: 0719-3726), 10(X), 2022:

http://dx.doi.org/

Table 2 Properties of Stone Aggregates and IBP

\begin{tabular}{|c|c|c|c|}
\hline Description of Tests & $\begin{array}{l}\text { Test Procedure } \\
\text { Code }\end{array}$ & Test Results & $\begin{array}{c}\text { Requirements } \\
\text { of MoRT\&H } \\
500-17\end{array}$ \\
\hline Combine Index, \% & IS-2386 Part 1 & $30.10 \%$ & $\leq 30 \%$ \\
\hline $\begin{array}{l}\text { Loss Angeles Abrasion Value, } \\
\%\end{array}$ & IS-2386 Part 4 & $26.01 \%$ & $\leq 30 \%$ \\
\hline Aggregate Impact Value, \% & IS-2386 Part 4 & $22.05 \%$ & $\leq 24 \%$ \\
\hline Water Absorption, \% & IS-2386 Part 3 & $0.3 \%$ & $\leq 2 \%$ \\
\hline Stripping, \% & IS-6241 & $98 \%$ & $\geq 95 \%$ \\
\hline Sp.gr of Stone CA & IS-2386 Part 3 & 2.67 & ------- \\
\hline Sp.gr of Stone FA & $\begin{array}{l}\text { IS-2720 Part } 3 \\
1980\end{array}$ & 2.76 & ------- \\
\hline Sp.gr of Stone MF & $\begin{array}{l}\text { IS-2720 Part } 3 \\
1980\end{array}$ & 2.84 & ------- \\
\hline Sp.gr of CSMF & $\begin{array}{l}\text { IS-2720 Part } 3 \\
1980\end{array}$ & 2.85 & ------- \\
\hline
\end{tabular}

In this present analysis, the Viscosity Grade of Bitumen VG30 [IS 73:2006] is used for the preparation of BC-2 mixtures and the results of the basic tests are shown in the table. 3 .

Table 3 Basic Properties of VG30 bitumen

\begin{tabular}{|c|c|c|c|}
\hline Description of Tests & $\begin{array}{l}\text { Test procedure } \\
\text { code }\end{array}$ & $\begin{array}{c}\text { Result } \\
\mathrm{s}\end{array}$ & $\begin{array}{l}\text { Requirements (IS } 73 \\
2006 \text { ) }\end{array}$ \\
\hline $\begin{array}{l}\text { Penetration value at } \\
25^{\circ} \mathrm{C}, 0.1 \mathrm{~mm}\end{array}$ & IS 12031978 & 68.33 & 50 to 70 \\
\hline Softening point, ${ }^{\circ} \mathrm{C}$ & IS 12051978 & 51.75 & $>47^{\circ} \mathrm{C}$ \\
\hline Ductility value, $27^{\circ} \mathrm{C}, \mathrm{cm}$ & IS 12081978 & 82.5 & -- \\
\hline $\begin{array}{l}\text { Specific gravity(Sp.gr) at } \\
27^{\circ} \mathrm{C}\end{array}$ & IS 12021978 & 1.00 & -- \\
\hline Flash Point, ${ }^{\circ} \mathrm{C}$ & IS 14481969 & 260 & $220^{\circ} \mathrm{C}$ \\
\hline $\begin{array}{l}\text { Viscosity test at } 135^{\circ} \mathrm{C}, \\
\text { cst }\end{array}$ & IS 12061978 & 390 & $>350$ cst \\
\hline
\end{tabular}


Sustainability, Agri, Food and Environmental Research, (ISSN: 0719-3726), 10(X), 2022:

http://dx.doi.org/

\section{Design of Mixture}

The Marshall Stability test procedure is used to determine the stability, flow and optimum bitumen content (OBC) of the mixture based on ASTM: D-1559-1979 [ASTMD1559,1979]. BC-2 with four different bitumen percentages are prepared at an increment of 0.5 percent ( 4.5 percent to 6 percent). ( 4.5 percent to 6.0 percent). Identical specimens are prepared with 0, 25, 50, 75 and 100 percent of CS-MF, respectively. Marshall Cylindrical Specimens are prepared and tested for bituminous concrete mixtures containing 0 , $25,50,75 \& 100$ percent CS-MF at OBC for the Marshall Test and are summarized in the table.

4.

Table 4 Marshall properties of BC2 mixtures with IBP-MF content

\begin{tabular}{lccccccc} 
MF content & $\begin{array}{c}\text { Stability, } \\
\mathrm{Kg}\end{array}$ & $\begin{array}{c}\text { Flow, } \\
\mathrm{mm}\end{array}$ & $\begin{array}{c}\text { Total air voids } \\
(\mathrm{Vv}), \%\end{array}$ & $\begin{array}{c}\text { Bulk Density } \\
(\mathrm{Gb}), \mathrm{g} / \mathrm{cc}\end{array}$ & $\begin{array}{c}\text { VMA, \% } \\
\%\end{array}$ & $\begin{array}{c}\text { VFB, } \\
\%\end{array}$ & $\begin{array}{c}\text { OBC, } \\
\%\end{array}$ \\
\hline IBPMF0\% & 2316 & 3.63 & 4.16 & 2.375 & 17.18 & 75.75 & 5.48 \\
CSMF25\% & 2338 & 3.57 & 4.17 & 2.374 & 16.92 & 75.34 & 5.37 \\
CSMF50\% & 2368 & 3.50 & 4.04 & 2.377 & 16.76 & 75.89 & 5.35 \\
CSMF75\% & 2477 & 3.33 & 3.94 & 2.378 & 16.62 & 76.30 & 5.33 \\
CSMF100\% & 2520 & 3.33 & 3.96 & 2.377 & 16.58 & 76.10 & 5.31
\end{tabular}

ITS Test

Static indirect tensile strength (SITS) tests are performed on Marshall specimens at varying temperatures of $25^{\circ} \mathrm{C}, 45^{\circ} \mathrm{C}, \& 65^{\circ} \mathrm{C}$ as per ASTM D 6931-12[ASTM D6931-2012]. The static indirect tensile strength is determined as given by Eqn. 1 The results obtained from the Static Indirect Tensile Strength test are shown in Fig. 2.

$$
\text { Indirect Tensile Strength }=\frac{2 P}{\pi d t}
$$

Where: SITS $=$ Static indirect tensile strength, $P=$ Failure load, $t=$ Thickness of specimen, $d$ = Diameter of specimen. 
Sustainability, Agri, Food and Environmental Research, (ISSN: 0719-3726), 10(X), 2022:

http://dx.doi.org/

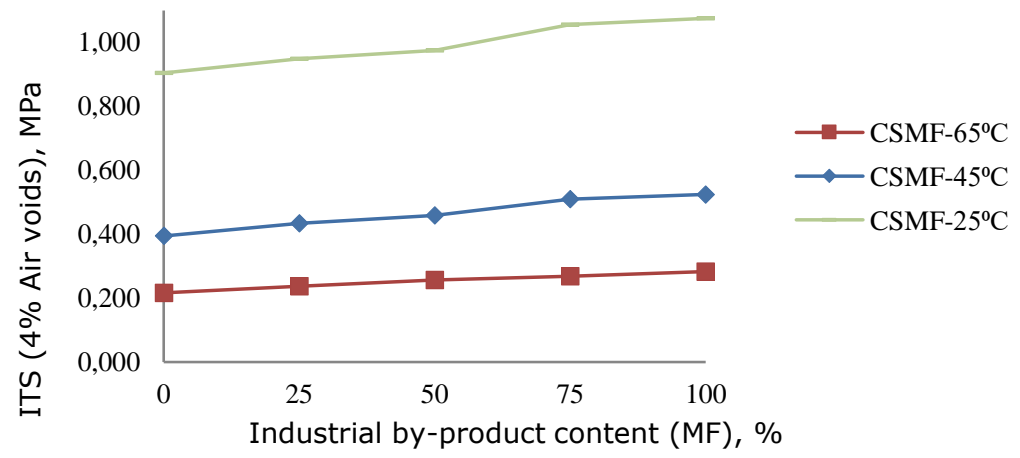

Fig. 2 Static indirect tensile strength v/s Industrial by-product content

Water Resistivity Test

Two sets of Marshall Specimens are prepared at OBC as per AASHTO T-283. The ratio of the ITS (static indirect tensile strength) of the conditioned Marshall cylindrical sample to the ITS of the unconditioned Marshall cylindrical sample gives TSR (static tensile strength ratio), the resulting TSR (split tensile strength ratio) results for 0, 25, 50, $75 \& 100$ percent CSMF at varying temperatures of $25^{\circ} \mathrm{C}, 45^{\circ} \mathrm{C}, \& 65^{\circ} \mathrm{C}$ are summarised in Table 5 .

Table 5 TSR of BC-2 Mixture with CSMF

\begin{tabular}{cccccc}
$\begin{array}{c}\text { Temperature, } \\
{ }^{\circ} \mathrm{C}\end{array}$ & CSMF0\% & CSMF25\% & CSMF50\% & CSMF75\% & CSMF100\% \\
\hline 25 & 0.857 & 0.864 & 0.860 & 0.864 & 0.868 \\
45 & 0.861 & 0.883 & 0.873 & 0.881 & 0.877 \\
65 & 0.852 & 0.895 & 0.899 & 0.877 & 0.864
\end{tabular}

SEM and EDXA

The surface morphology and shape of the CSMF was studied by means of a SEM (Scanning Electron Microscope) and are shown in Fig.3. The recorded CSMF SEM micrographs shows varying texture and morphology. This is an important aspect because the surface structure influences the tendency of bituminous mixtures to bind to copper slag. This is also an important parameter for obtaining a bituminous concrete mixture of enhanced durability and stability for 25, 50, 75 \& 100 percent CSMF replacement. EDXA (Energy Dispersive X-ray Analyzer), which is an X-ray chemistry tool, is used to investigate the elementary composition of CS-MF and the findings of the experiment are summarized in Table.6. 
Sustainability, Agri, Food and Environmental Research, (ISSN: 0719-3726), 10(X), 2022:

http://dx.doi.org/

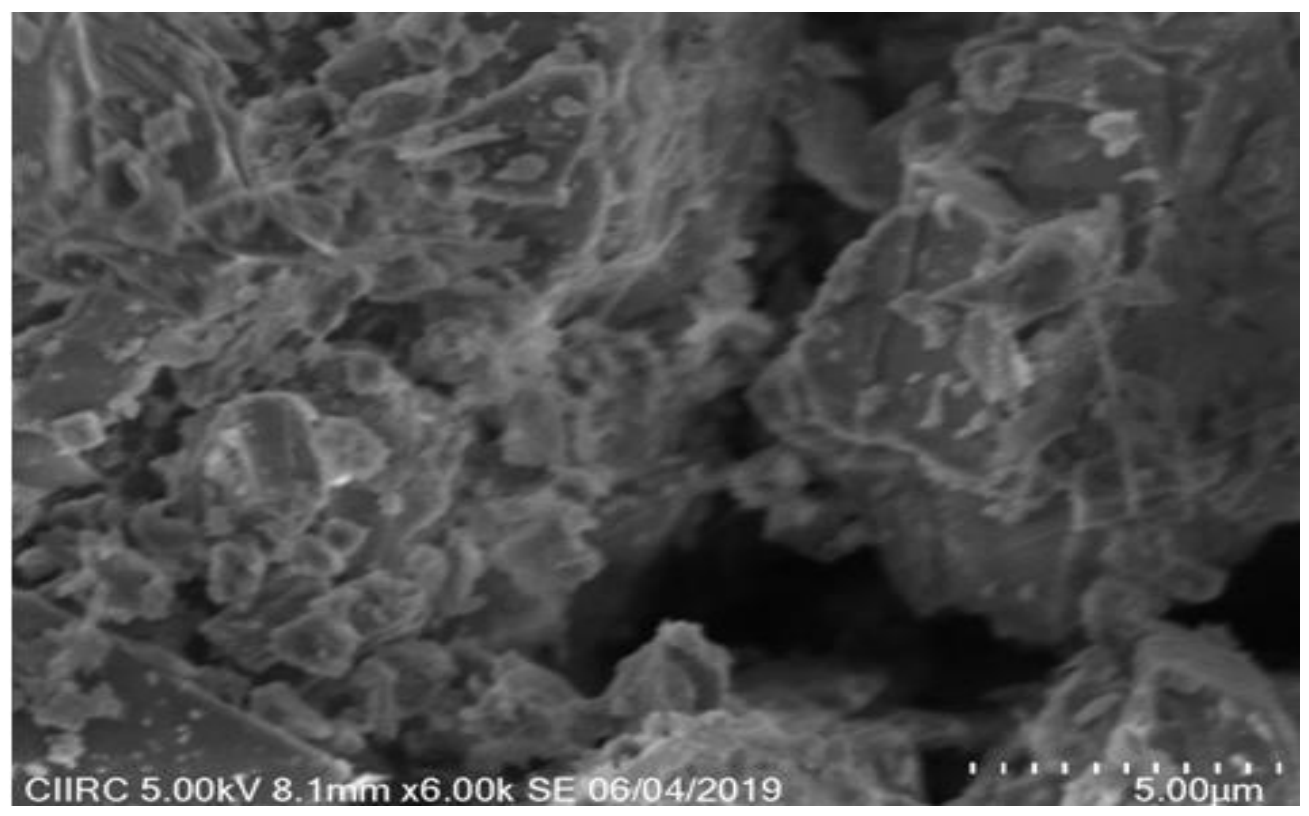

Fig. 3 SEM micrographs of CS-MF

Table 6 Quantitative elemental composition of CS material

\begin{tabular}{ccc}
$\begin{array}{c}\text { Element } \\
\text { Line }\end{array}$ & Weight, \% & Atom, \% \\
\hline C K & 2.72 & 5.02 \\
O K & 30.77 & 42.57 \\
F K & 1.19 & 1.39 \\
Na K & 2.45 & 2.36 \\
Al K & 10.66 & 8.74 \\
Si K & 46.75 & 36.84 \\
Si L & ---- & ---- \\
K K & 5.45 & 3.08 \\
K L & ---- & ---- \\
Total & 100 & 100
\end{tabular}

\section{RESULTS AND DISCUSSION}

From Table 4, it is also observed that, for BC2 mixture replaced with CS-MF, the OBC is found to decrease from CSMF25\% to maximum CSMF100\% replacement; however, the decrease in the optimal bitumen content becomes negligible after CSMF75\% replacement. The high stability and static ITS values obtained for BC2 mixtures with CSMF could be due to 
Sustainability, Agri, Food and Environmental Research, (ISSN: 0719-3726), 10(X), 2022:

http://dx.doi.org/

its angular shape and rough texture of copper slag particle resulting in enhanced mechanical properties of BC2 mixtures. The effect of CS material on moisture resistivity of bituminous concrete mixtures is determined by conducting the Water Resistivity test. Obtained results are shown in Table 5. Mixtures with CSMF replacement satisfy the section 500 Table $517 \& 519$ of MoRT\&H 4th revision specifications (MoRT\&H 2001).

Quantitative elemental composition of Copper slag shows that high percentage of weight and atom of Silica in Copper slag compare to traditional filler.

The main objective of this experiment is to analyse the strength characteristics of BC2 mixtures using CSMF. The condensation of the conclusions of the experimental studies is presented below.

Based on the obtained digital image by SEM micrographs of mineral filler (MF) of CS material are very rough in surface texture and angular in shape compared to traditional materials. CS materials as MF provides effective interlocking and friction in the bituminous concrete mixtures which result in higher Marshall stability value, decreases in optimum bitumen content, increases in bulk density, and improvement in ITS value compared to conventional mixtures. Also high percentage of Silica and atom percentage in copper slag, which enhances the good resistance to moisture-induced damage as seen in split tensile strength ratio (TSR) test results.

The TSR (Tensile Strength Ratio) of the bituminous mixtures at OBC for 0, 25, 50, 75 $\& 100$ percent CSMF replacement satisfy the requirements as per Section 500, Table No. 50017 for BC-2 Mixtures.

Within the limits of the experimental analysis carried out in this report, copper slag can be effectively used as mineral filler since it meets the specifications.

\section{REFERENCES}

Huang Y, Bird RN, Heidrich O. A review of the use of recycled solid waste materials in asphalt pavements. Resour Conserv Recycl 2007;52:58-73.

Pundhir N K, Kamaraj C and Nanda P K, "Use of copper slag as construction material in bituminous pavements", Journal of Scientific \& Industrial Research, Vol. 64, no.2, (2005), pp. 997-1002.

B. Jayashree, S. Santhanu and B.Kalaiarasan, "Utilization of Copper slag in bituminous mix", International Journal of Chemical science, Vol.14, No.1, (2016), pp. 188-202.

K.R. Sankarlal, Dr. E. Ravi and Dr. S. Palanivelraja, "A study of alternative materials for flexible pavement using Copper slag, Fly ash and Waste plastics in bituminous 
Sustainability, Agri, Food and Environmental Research, (ISSN: 0719-3726), 10(X), 2022:

http://dx.doi.org/

concrete", International Journal of Engineering Research and Technology, Vol. 6, No.12, (2017), pp. 342-345.

Havanagi V G, Singa A K, Prasad P S, Sitaramanjaneyulu M E and Mathur S, "Copper slag as an alternative material for road construction", In: Proceedings of the 24th International

Conference on Solid Waste Technology and Management, Philadelphia, PA, USA, (2009), pp. 133-144.

Hassan $\mathrm{H} \mathrm{F}$ and Al-Jabri K, "Laboratory evaluation of hot-mix asphalt concrete containing copper slag aggregate", Journal of Materials in Civil Engineering, Vol. 23, No.6, (2011), pp. 879-885.

Specifications for Road and Bridge works (4th Revision) Ministry of Road Transport \& Highways, Government of India, Indian Roads Congress, New Delhi, (2001).

Bureau of Indian standards for paving bitumen - specification IS 73:2006, BIS, New Delhi, (2006).

ASTM D1559, "Test Method for Resistance of Plastic Flow of Bituminous Mixtures Using Marshall Apparatus", ASTM International, West Conshohocken, PA, USA, (1979).

ASTM D6931-12, "Standard Test Method for Indirect Tensile (IDT) Strength of Bituminous Mixtures", ASTM International, West Conshohocken, PA, USA, (2012).

AASHTO T 283, "Standard Method of Test for Resistance of Compacted Asphalt Mixtures to Moisture-Induced Damage", AASHTO, Washington, DC, USA, (2014).

Received: 30th January 2021; Accepted: $10^{\text {th }}$ March 2021; First distribution: 01th April 2021 